\title{
Prevalence and Risk Factors for Iron Deficiency Anemia and Iron Depletion During Pregnancy: A Prospective Study
}

\author{
Prevalência e Factores de Risco Para Anemia \\ Ferropénica e Ferropénia Durante a Gravidez: Um \\ Estudo Prospectivo
}

\author{
Ana Gomes da COSTA ${ }^{1}$, Sara VARGAS ${ }^{1}$, Nuno CLODE $^{1,2}$, Luís M. GRAÇA ${ }^{1,2}$ \\ Acta Med Port 2016 Sep;29(9):514-518 - http://dx.doi.org/10.20344/amp.6808
}

\section{ABSTRACT}

Introduction: Anemia and iron deficiency during pregnancy are a worldwide concern and are more frequent among women of reproductive age, pregnant women, and young children. The aim of this study was to assess the prevalence of iron deficiency anemia and the risk factors for iron depletion during the first half of pregnancy, in a Portuguese population.

Material and Methods: A prospective study was conducted at a tertiary hospital and included pregnant women, until the 20th week of gestation. Data was collected regarding demographic and pregnancy features and hemoglobin and serum ferritin concentrations were determined. A multivariate logistic regression was performed to identify potential risk factors for iron deficiency.

Results: Two hundred and one women were included, from which five $(2.49 \%)$ presented anemia. Additionally, $77(38.3 \%)$ exhibited iron deficiency and $22(10.9 \%)$ revealed severe iron depletion. Maternal age was the only risk factor identified. The odds ratio (OR) was equal to $12.99(95 \% \mathrm{Cl} 2.41-70.0)$ for women under twenty years of age and $2.09(95 \% \mathrm{Cl} 1.05-4.14)$ for women older than thirty years of age.

Discussion and Conclusion: The prevalence of maternal anemia in the first half of pregnancy was lower than in other studies. However, more than one-third of the women exhibited iron deficiency. With the exception of maternal age, no other risk factors were identified.

Keywords: Anemia, Iron-Deficiency; Hematologic; Iron/metabolism; Pregnancy; Pregnancy Complications, Prevalence; Risk Factors.

\section{RESUMO}

Introdução: A anemia e a carência de ferro são problemas de saúde globais e são mais frequentes em grávidas, mulheres em idade reprodutiva e crianças. O objetivo deste trabalho consistiu na avaliação da prevalência de anemia ferropénica e dos fatores de risco associados à ferropénia, na primeira metade da gravidez, numa amostra da população portuguesa.

Material e Métodos: Estudo prospetivo, conduzido num hospital terciário, que incluiu grávidas até à $20^{a}$ semana de gestação. Foram coletados dados demográficos, relativos à gravidez e foram determinados os níveis séricos de hemoglobina e de ferritina no sangue materno. Recorreu-se à análise de regressão logística de variáveis múltiplas para identificar potenciais fatores de risco para ferropénia. Resultados: Foram incluídas 201 grávidas, das quais cinco (2,49\%) tinham anemia. Para além disso, 77 grávidas (38,3\%) tinham carência de ferro e $22(10,9 \%)$ apresentaram ferropénia grave. A idade materna foi o único fator de risco identificado. O odds ratio foi de 12,99 (95\% IC 2,41 - 70,0) para grávidas com idade inferior a 20 anos e de 2,09 (95\% IC 1,05 - 4,14), para grávidas com idade superior a 30 anos.

Discussão e Conclusão: Na nossa amostra, a prevalência de anemia na primeira metade da gravidez foi inferior à reportada noutros estudos. No entanto, mais de $30 \%$ das grávidas apresentaram carência de ferro. A idade materna foi o único fator de risco identificado. Palavras-chave: Anemia Ferropénica; Complicações Hematológicas na Gravidez; Factores de Risco; Ferro/metabolism; Gravidez; Prevalência.

\section{INTRODUCTION}

Anemia and iron deficiency affect billions of people worldwide and are more common among women of reproductive age, pregnant women, and young children. Globally, anemia is found in more than $20 \%$ of pregnancies. The highest rates are found in developing countries, with an estimated prevalence of $55.8 \%$ and $41.6 \%$ in Africa and Asia, respectively. ${ }^{1-3}$ In developed countries, according to the World Health Organization (WHO), this percentage falls to $18 \% .^{1,4}$ In Portugal, following the Empire Study, the incidence of anemia is slightly higher (19.9\%) and is more common in pregnancy. ${ }^{5}$

During pregnancy, anemia is defined as a hemoglobin
$(\mathrm{Hb})$ concentration < $11.0 \mathrm{~g} / \mathrm{dL}$ in the first and third trimesters and $\mathrm{Hb}<10.5 \mathrm{~g} / \mathrm{dL}$ in the second trimester. ${ }^{6}$ Multiple factors may lead to anemia during this period, namely nutritional deficiencies, hemolysis and abnormal hemoglobin synthesis, blood loss, defective iron absorption and metabolism, and chronic conditions. ${ }^{7}$

Iron-deficiency (ID) is the most common cause of anemia in pregnancy. The spectrum of ID ranges from iron depletion, to deficient erythropoiesis and to iron deficient anemia. ${ }^{6,8}$ The prevalence of ID can be 2 - 2.5 times that of iron deficiency anemia (IDA). The risk factors related to IDA include teenage pregnancy, high parity, multiple

1. Departamento de Ginecologia, Obstetrícia e Medicina da Reprodução. Hospital de Santa Maria. Centro Hospitalar Lisboa Norte. Lisboa. Portugal.

2. Faculdade de Medicina. Universidade de Lisboa. Centro Académico de Medicina. Lisboa. Portugal.

$\triangle$ Autor correspondente: Ana Gomes da Costa. ana.ofgc@gmail.com

Recebido: 15 de julho de 2015 - Aceite: 08 de março de 2016 | Copyright @ Ordem dos Médicos 2016 
pregnancies and reduced inter-pregnancy intervals. ${ }^{2,7} \mathrm{~A}$ previous study analysed the iron status of pre-pregnant women and concluded that $36.5 \%$ of these had low iron stores, therefore presenting a higher risk of becoming iron deficient during their pregnancy. ${ }^{8}$ Furthermore, iron requirements increase for pregnant women and are difficult to achieve by diet alone. 1,3,6 $^{1}$

Iron deficiency anemia has been linked to negative maternal-fetal outcomes. For mothers, these include reduced working and intellectual capacity, increased susceptibility to infection, higher risk of post-partum anemia and depression. . $^{2,9}$ The perinatal outcomes include premature delivery, small for gestational age infants, a highest risk of anemia and poor physical and mental growth during infancy. ${ }^{2,7,9-11}$ Therefore, the diagnosis of IDA and its treatment has a positive impact. 2,9,11,12 Moreover, current guidelines recommend a daily iron supplementation of at least $60 \mathrm{mg}$ of elemental iron after the $16^{\text {th }}-20^{\text {th }}$ week of gestation or sooner if there are any risk factors. ${ }^{1,13,14}$

The iron status can be determined by a serum ferritin (SF) assay that has the highest sensitivity and specificity to diagnose iron deficiency. ${ }^{7,15}$ Serum ferritin identifies iron deficiency earlier than other biomarkers such as $\mathrm{Hb}$ and transferring saturation (TS) but can be increased in the presence of inflammation or infection. If SF is $<30 \mu \mathrm{g} / \mathrm{L}$, there is a $90 \%$ certainty that the iron stores are depleted, even if there is no anemia. A value $<15 \mu \mathrm{g} / \mathrm{L}$, provides clear evidence for IDA. ${ }^{7,9,11}$

The treatment of IDA depends on the severity of the anemia. In mild cases, the primary treatment includes oral iron therapy. In more severe cases, intravenous iron may be used as parenteral iron results in a faster increase in $\mathrm{Hb}$ levels. If a critical value of $\mathrm{Hg}$ is achieved, blood transfusion has to be considered. ${ }^{12,14,15}$

With this study we seek to assess the occurrence of anemia and iron deficiency in a Portuguese population, as well as the risk factors for iron deficiency during the first half of pregnancy.

\section{MATERIAL AND METHODS}

A prospective study was conducted between February 2013 and September 2014 at the Department of Obstetrics and Gynecology of Hospital de Santa Maria, a tertiary university/public hospital in Lisbon, Portugal. In our Hospital, there are about 2,300 deliveries per year. The study was approved by the Hospital's Ethics Committee (Protocol number 936/12). An informed consent was obtained before enrolment.

All women attending their first hospital visit for antenatal care at 20 weeks or less were invited to participate in the present study. Exclusion criteria included iron supplementation, clinical history of hematological disease, chronic inflammation, infection or malignancies, and blood transfusions in the previous 6 months.

At their first medical appointment, clinical and obstetric histories were thoroughly collected and venous blood samples were taken for a full blood count and serum

ferritin determination. Serum ferritin was measured by quimiluminescent assay.

Baseline data was also collected, comprising maternal age, ethnic group, parity, body mass index (BMI), smoker status, level of education, single/multiple gestation and gestational age at the time when laboratory tests were performed.

Table 1 - Demographic characteristics*

$\begin{array}{ll}\text { Age (years) } & 31.0(14-45) \\ \text { Race } & \\ \text { Caucasian } & 168(83.6 \%) \\ \text { Black } & 33(16.4 \%) \\ \text { Parity } & \\ 0 & 121(60.2 \%) \\ 1 & 57(28.4 \%) \\ 2 & 13(6.5 \%) \\ 3-5 & 10(5.0 \%) \\ \text { Gestational age (weeks) } & 11.2 \pm 3.1\end{array}$

Pregnancy

Simple

Multiple

$186(92.5 \%)$

BMI $\left(\mathrm{kg} / \mathrm{m}^{2}\right)$

$15(7.5 \%)$

$24.5(16-45)$

Origin of mother

$\begin{array}{ll}\text { Europe + North America } & 165(82.1 \%) \\ \text { Africa } & 28(13.9 \%) \\ \text { South America } & 8(4.0 \%)\end{array}$

Education

$\begin{array}{ll}\text { Primary } & 12(6.0 \%) \\ \text { Lower secondary } & 30(14.9 \%) \\ \text { Upper secondary } & 71(35.3 \%) \\ \text { University degree } & 88(43.8 \%)\end{array}$

Interpregnancy interval $(n=80)$

$\begin{array}{ll}<1 \text { year } & 8(10 \%) \\ 1-2 \text { years } & 8(10 \%) \\ \geq 2 \text { years } & 64(80 \%)\end{array}$

Smoking status

Smokers

$47(23.4 \%)$

Non-smokers

$154(76.6 \%)$

Nutritional status

$\begin{array}{ll}\text { Vegetarian } & 2(1.0 \%) \\ \text { Non-vegetarian } & 199(99 \%)\end{array}$

*Values are given as median (range) or numbers (percentage) unless otherwise indicated. BMI: Body mass index 
Anemia was defined as $\mathrm{Hb}<11.0 \mathrm{~g} / \mathrm{dL}$ in the first trimester (before the $14^{\text {th }}$ week of pregnancy) and $10.5 \mathrm{~g} / \mathrm{dL}$ in the second (from the $14^{\text {th }}$ to the $27^{\text {th }}$ week of pregnancy). Iron depletion was defined as a SF $<30 \mathrm{mg} / \mathrm{L}$ and severe iron depletion as a SF $<15 \mathrm{mg} / \mathrm{L}$. Two groups of women were compared based on the concentration of SF: without iron deficiency (SF $\geq 30 \mathrm{mg} / \mathrm{L}$ ) and with iron deficiency (SF $<30$ $\mathrm{mg} / \mathrm{L})$. The following potential risk factors were examined: age, race, parity, body mass index, multiple gestations, level of education and smoker status. For a secondary outcome of this study, a sub-analysis was conducted to analyse women with severe iron depletion (SF < $15 \mathrm{~m} / \mathrm{L}$ ).

Statistical analysis was performed with SPSS software version 2.0 (SPSS Inc., Chicago, IL, USA). A sample size was calculated to evaluate the prevalence of maternal anemia, and, for a maximum error of 0.05 , ninety women had to be enrolled in the study.

The Kolmogorov-Smirnoff test was used to assess the normality of the data distribution. Student's t Test and MannWhitney $U$ test were performed to compare continuous variables. The Fisher's exact test and Pearson $X^{2}$ test were used to compare categorical variables.

Multivariate logistic regression analysis was performed to analyse potential risk factors for decreased iron stores. $p$-value $<0.05$ was considered to be statistically significant.

\section{RESULTS}

Two hundred and one women were included, whose demographic characteristics are shown in Table 1. The median of maternal age was 31 years and the mean gestational age at enrolment was $11.2 \pm 3.1$ weeks. The mean hemoglobin concentration at the baseline was 12.8 $\pm 0.9 \mathrm{~g} / \mathrm{dL}$ and the median of serum ferritin was $39.0 \mathrm{mg} / \mathrm{L}$ (3.8 - $245.0 \mathrm{mg} / \mathrm{L})$.

In the study group, the prevalence of maternal anemia was $2.49 \%$ (5/201). However, $38.3 \%$ (77 women) already showed decreased levels of iron (SF $<30 \mathrm{mg} / \mathrm{L}$ ). Out of these, $10.9 \%$ (22 women) had severe iron depletion, defined as SF $<15 \mathrm{mg} / \mathrm{L}$.

Overall, there were no statistically significant differences between women with normal SF and depleted iron stores regarding maternal age, race, parity, BMI, smoker status, university degree, multiple gestation and gestational age at enrolment in the study. The sub-analysis between women with normal SF and with severe iron deficiency (SF $<15$ $\mathrm{mg} / \mathrm{L}$ ) didn't show any differences as well, except for the haemoglobin level, which was lower in the last group (Table 2).

However, the multivariate logistic regression analysis showed that the odds ratio for iron deficiency increased in younger and older women. The odds ratio (OR) was 12.99 $(95 \% \mathrm{Cl} 2.41-70.0)$ for women under twenty years of age and $2.09(95 \% \mathrm{Cl} 1.05-4.14)$ for women over thirty years of age. In our study, race, parity, BMI, multiple gestation, level of education and smoker status were not linked to an increased risk of iron deficiency (Table 3).

\section{DISCUSSION AND CONCLUSION}

Anemia and iron status are important determinants of maternal and infant health and are linked to negative pregnancy outcomes. ${ }^{3}$ Data on maternal anemia and its predictors is limited in Portugal as few studies were published.

Our study group showcased a $2.5 \%$ prevalence of anemia, lower than the one reported in other studies, ${ }^{1,16-18}$ with the exception of a Swiss study that also reported a low prevalence of IDA during pregnancy (3\%). ${ }^{19}$ The lower prevalence of IDA may be due to the demographic features of our study group, which only included women until the $20^{\text {th }}$ week of pregnancy. As anemia during pregnancy increases more than a 4-fold from the first to the third trimester, the prevalence of anemia would be probably higher in late pregnancy, in women without iron supplementation.

As expected, the prevalence of iron depletion was higher than IDA. In the first half of the pregnancy, more than one-third of our study group had low serum ferritin

Table 2 - Comparison of the demographic characteristics between groups: serum ferritin $\geq 30 \mu \mathrm{g} / \mathrm{L} v s$ serum ferritin $<30 \mu \mathrm{g} / \mathrm{L}$ and serum ferritin $\geq 30 \mu \mathrm{g} / \mathrm{L}$ vs serum ferritin $<15 \mu \mathrm{g} / \mathrm{L}^{*}$

\begin{tabular}{|c|c|c|c|c|c|}
\hline & $\begin{array}{c}\text { Ferritin } \geq 30 \\
n=124(61.7 \%)\end{array}$ & $\begin{array}{c}\text { Ferritin }<30 \\
\mathrm{n}=77(38.3 \%)\end{array}$ & $p$-value & $\begin{array}{c}\text { Ferritin }<15 \\
\mathrm{n}=22(10.9 \%)\end{array}$ & $p$-value \\
\hline Age (years) & $32(14-45)$ & $30(16-45)$ & 0.667 & $29(17-41)$ & 0.096 \\
\hline Race (caucasian) & $103(83.1 \%)$ & $65(84.4 \%)$ & 0.956 & $19(86.4 \%)$ & 0.942 \\
\hline Parity (nuliparity) & $79(63.7 \%)$ & $42(54.5 \%)$ & 0.253 & $13(59.1 \%)$ & 0.862 \\
\hline Gestational age (weeks) & $11(4-18.57)$ & $10.14(5.14-19)$ & 0.402 & $9.86(6.57-18)$ & 0.413 \\
\hline Multiple pregnancy & $9(7.3 \%)$ & $6(7.8 \%)$ & 0.892 & $2(9.1 \%)$ & 0.89 \\
\hline BMI $\left(\mathrm{kg} / \mathrm{m}^{2}\right)$ & $24.6(16.3-44.7)$ & $23.8(18-43.4)$ & 0.745 & $22.5(18.3-38.1)$ & 0.245 \\
\hline $\mathrm{Hb} 1^{\text {st }}$ Trimester & $12.8(10.9-15.1)$ & $12.7(10.2-15.3)$ & 0.212 & $12.3(10.2-14.6)$ & 0.016 \\
\hline Education (university degree) & $55(44.4 \%)$ & $33(42.9 \%)$ & 0.951 & $8(36.4 \%)$ & 0.643 \\
\hline Smoking status (smokers) & $29(23.4 \%)$ & $18(23.4 \%)$ & 0.865 & $3(13.6 \%)$ & 0.519 \\
\hline
\end{tabular}

* Data expressed as median (range) or $\mathrm{n}(\%)$. BMI: Body mass index; Hb: Haemoglobin. 
Table 3 - Multivariate logistic regression analysis of the factors associated to iron deficiency

\begin{tabular}{|c|c|c|}
\hline & \multicolumn{2}{|c|}{ Decreased iron stores* } \\
\hline & Odds ratio & 95\% Confidence Interval \\
\hline \multicolumn{3}{|l|}{ Age (years) } \\
\hline$<20$ & 12.99 & $2.41-70.0$ \\
\hline 20 - 30 (reference category) & 1 & - \\
\hline$>30$ & 2.09 & $1.05-4.14$ \\
\hline \multicolumn{3}{|l|}{ Race } \\
\hline Black & 0.91 & $0.35-2.38$ \\
\hline \multicolumn{3}{|l|}{ Parity } \\
\hline $2-3$ & 0.61 & $0.18-2.11$ \\
\hline$>4$ & 4.51 & $0.45-45.76$ \\
\hline \multicolumn{3}{|l|}{ Body mass index } \\
\hline 18.5 - 24 (reference category) & 1 & - \\
\hline$<18.5$ & 1.16 & $0.18-7.64$ \\
\hline $25-29$ & 1.29 & $0.57-2.89$ \\
\hline$\geq 30$ & 1.87 & $0.72-4.85$ \\
\hline Multiple gestation & 0.78 & $0.11-5.5$ \\
\hline \multicolumn{3}{|l|}{ Education } \\
\hline University degree (reference category) & 1 & - \\
\hline Primary & 0.562 & $0.12-2.63$ \\
\hline Lower secondary & 1.43 & $0.53-3.87$ \\
\hline Upper secondary & 1.03 & $0.5-2.14$ \\
\hline Smokers & 0.99 & $0.47-2.12$ \\
\hline
\end{tabular}

* Serum ferritin $<30 \mu \mathrm{g} / \mathrm{l}$

concentrations (SF $<30 \mathrm{mg} / \mathrm{L}$ ) and $11 \%$ had severe iron depletion. In agreement with former studies, our findings conclude that maternal age is a risk factor for iron deficiency in the first half of pregnancy. Women older than thirty-yearsold had a 2-fold higher risk of iron deficiency and women under twenty-years-old had almost a 13-fold higher risk for iron deficiency. No other risk factors were found among our study parameters, which also included race, body mass index, level of education and smoker status. We also did not find a correlation between parity and lower serum ferritin concentrations. Unexpectedly, the prevalence of IDA and iron deficiency didn't differ between simple and multiple pregnancies. However, due to the small number of multiple pregnancies included $(n=15)$, these results should be interpreted with caution.

These results are relevant given the lack of data regarding anemia during pregnancy in Portugal, and to alert clinicians to the high prevalence of iron depletion in pregnant women, becoming at risk of developing anemia. The best moment to evaluate maternal iron status is in the early stages of pregnancy, before the plasma is fully expanded. Also, in the first trimester, it may be beneficial to evaluate the serum ferritin, to identify women with iron depletion and at risk of anemia. ${ }^{6}$ A low SF may warrant an early intervention and iron status improvement with iron supplementation. The positive effects of adequate iron supplementation during pregnancy are well known and include improved birth weight and reduction in preterm labour and perinatal morbidity. These effects extend into the postnatal period with improved maternal $\mathrm{Hb}$ concentrations four to eight weeks postpartum. 2,20,21 $^{2}$

Nonetheless, clinicians should also be aware of the increased risk of adverse maternal and neonatal outcomes linked to excess of iron and high hemoglobin concentrations. Studies have found an increased risk of low birth weight, preterm birth and small for gestational age infants, while others have showed that iron supplementation in nonanemic women did not affect birth weight. ${ }^{20,21}$ Therefore, iron supplementation in pre-pregnancy and early in pregnancy may be considered, only for women with low serum ferritin concentration and anemia. .,12,20 $^{2}$

This study presents some limitations. It included only 
fifteen multiple pregnancies which is probably insufficient to provide reliable conclusions regarding this group. As in most studies, we used a cut-off of $30 \mathrm{mg} / \mathrm{L}$ to define iron deficiency. However, lower cut-offs have been used (ex. SF $<20 \mathrm{mg} / \mathrm{L}$ ), sustaining why the prevalence of iron deficiency in our study may be higher. To minimize this constraint a sub-analysis was performed to evaluate pregnant women with severe iron depletion ( $\mathrm{SF}<15 \mathrm{mg} / \mathrm{L}$ ).

Although SF is the best biochemical parameter for iron deficiency, a known limitation of this marker is that it increases with inflammation, infection or malignancy. Some authors believe that transferrin saturation (TS) should also be determined to identify errors, as its value doesn't increase with inflammation. In addition, an assessment of C-reactive protein (CRP) levels would help to identify those cases. We didn't determine the TS nor the CRP, as it would add additional costs to the study. However, the clinical history of each potential participant was thoroughly collected, prior to their enrolment, to exclude those with evidence of infection or inflammation.

Although our sample includes healthy women with uncomplicated pregnancies surveyed at our prenatal consult, we should be cautioned when generalizing these findings to the general population. For that, more studies should be conducted, preferably multicentre, and in Health Centres in order to gather a larger group of eligible subjects.

In conclusion, our findings indicate that, although maternal anemia in the first half of pregnancy seems to be

\section{REFERENCES}

1. de Benoist B, McLean E, Egli I, Cogswell M. Worldwide prevalence of anemia 1993-2005. WHO Global Database on Anemia. Geneva: World Health Organization; 2008. [Consulted 2014 Nov 10]. Available from http://whqlibdoc.who.int/publications/2008/9789241596657_eng.df.

2. Goonewardene M, Shehata M, Hamad A. Anemia in pregnancy. Best Pract Res Clin Obstet Gynaecol. 2012;26:3-24.

3. Berger J, Wieringa FT, Lacroux A, Dijkhuizen MA. Strategies to prevent iron deficiency and improve reproductive health. Nutr Rev. 2011;69:7886.

4. WHO World Health Organization, UNO UNICEF. Iron deficiency anemia: assessment, prevention and control. A guide for program managers. WHO/NHD/01.3. [consulted 2014 Nov 10]. Available from http://www.who.int/nutrition/publications/en/ida_assessment_ prevention_control.pdf2001.

5. Fonseca C, Marques F, Robalo Nunes A, Belo A, Brilhante D, Cortez J. Prevalence of anemia and iron deficiency in Portugal: the EMPIRE study. Intern Med J. 2016;46:470-8.

6. Scholl TO. Maternal iron status: relation to fetal growth, length of gestation, and iron endowment of the neonate. Nutr Ver. 2011;69:23-9.

7. ACOG Practice bulletin No.95: Anemia in pregnancy. Obstet Gynecol. 2008;112:201-7.

8. Aranda N, Ribot B, Garcia E, Viteri FE, Arija V. Pre-pregnancy iron reserves, iron supplementation during pregnancy, and birth weight. Early Hum Dev. 2011;87:791-7.

9. Breymann C, Honegger C, Holzgreve W, Surbek D. Diagnosis and treatment of iron-deficiency anemia during pregnancy and postpartum. Arch Gynecol Obstet. 2010;282:577-80.

10. Ribot B, Aranda N, Viteri F, Hernández-Martínez C, Canals J, Arija V. Depleted iron stores without anemia early in pregnancy carries increased risk of lower birthweight even when supplemented daily with moderate iron. Hum Reprod. 2012;27:1260-6.

11. Milman N. Oral iron prophylaxis in pregnancy: not too little and not too lower in Portugal than in other countries, more than onethird of the study subjects had low ferritin concentrations and increased risk of anemia. Maternal age was the only risk factor identified, especially for teenage women, implying that iron depletion may affect all pregnant women, regardless of race, parity, body mass index, level of education and smoker status. Maternal anemia and iron deficiency are preventable risks factors for adverse maternal and birth outcomes, and iron supplementation may be considered not only after the $16^{\text {th }}-20^{\text {th }}$ week of pregnancy but also earlier if iron reserves are low. Despite our results, more studies should be conducted,

\section{PROTECTION OF HUMANS AND ANIMALS}

The authors declare that The study was approved by the Hospital's Ethics Committee (Protocol number 936/12) and carried out according to the Helsinki Declaration of the World Medical Association.

\section{DATA CONFIDENTIALITY}

The authors declare having followed the protocols in use at their working center regarding patients' data publication.

\section{CONFLICTS OF INTEREST}

The authors report no conflict of interest.

\section{FUNDING SOURCES}

No subsidies or grants contributed to this work.

much! J Pregnancy. 2012;2012:514345.

12. Haider BA, Olofin I, Wang M, Spiegelman D, Ezzati M, Fawzi WW. Anemia, prenatal iron use, and risk of adverse pregnancy outcomes: systematic review and meta-analysis. BMJ. 2013;346:f3443.

13. Peña-Rosas JP, De-Regil LM, Dowswell T, Viteri FE. Daily oral iron supplementation during pregnancy. Cochrane Database Syst Rev. 2012;12:CD004736.

14. Reveiz L, Gyte GM, Cuervo LG, Casasbuenas A. Treatments for iron-deficiency anemia in pregnancy. Cochrane Database Syst Rev. 2011;10:CD003094.

15. Khalafallah AA, Dennis AE. Iron deficiency anemia in pregnancy and postpartum: pathophysiology and effect of oral versus intravenous iron therapy. J Pregnancy. 2012;2012:630519.

16. Barroso F, Allard S, Kahan BC, Connoly C, Smethurst H, Choo L, et al. Prevalence of maternal anemia and its predictors: a multi-centre study. Eur J Obstet Gynecol Reprod Biol. 2011;159:99-105.

17. Bencaiova G, Burkhardt T, Breymann C. Anemia - prevalence and risks factors in pregnancy. Eur J Intern Med. 2012;23:529-33.

18. Noronha JA, Bhaduri A, Vinod Bhat H, Kamath A. Maternal risk factors and anemia in pregnancy: a prospective retrospective cohort study. J Obstet Gynaecol. 2010;30:132-6.

19. Hess SY, Zimmermann MB, Brogli S, Hurrell RF. A national survey of iron and folate status in pregnant women in Switzerland. Int J Vitam Nutr Res. 2001;71:268-73.

20. Peña-Rosas JP, Viteri FE. Effects and safety of preventive oral iron or iron+folic acid supplementation for women during pregnancy. Cochrane Database Syst Rev. 2009;4:CD004736.

21. Parker JA, Barroso F, Stanworth SJ, Spiby H, Hopewell S, Doree CJ, et al. Gaps in the evidence for prevention and treatment of maternal anemia: a review of systematic reviews. BMC Pregnancy Childbirth. 2012;12:56-66. 